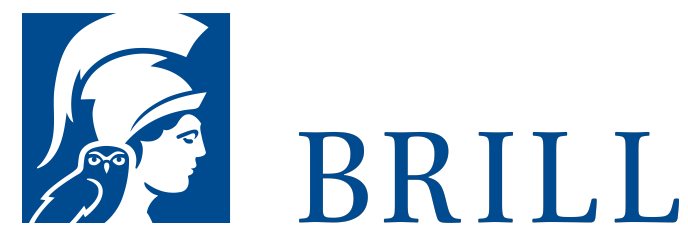

\title{
Konzil und Codex
}

Zur Hermeneutik des Kirchenrechts am Beispiel der christifideles laici

Author: Thomas Meckel

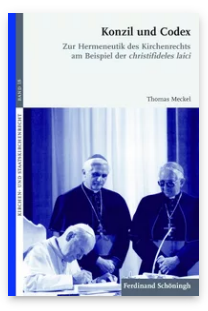

Ist das Konzil Verständnis- und Auslegungshorizont für den Codex oder umgekehrt? Diese Arbeit widmet sich zunächst grundsätzlich dem Verhältnis von Konzil und Codex, das für die Hermeneutik und die Methodik der Kirchenrechtswissenschaft von immenser Bedeutung ist. Nicht selten hört man in der kirchlichen Praxis, dass die Gläubigen nicht mehr versorgt und angesichts der Überlastung vieler Pfarrer Aufgaben an Laien delegiert werden. Hinter solchen Vorstellungen verbirgt sich häufig ein noch an der Katholischen Aktion des 19. und frühen 2o. Jahrhunderts orientiertes Verständnis des Laienapostolats. Dies zeigt, dass die Erneuerung des Laienapostolats durch das Zweite Vatikanische Konzil und die erneuerte Rechtsordnung der Kirche in Teilen nicht bzw. noch nicht rezipiert wurden. Ist der Laie mehr als nur ein Nichtkleriker? Lässt sich der Begriff des Laien in der Kirche auch positiv füllen? Vor dem Hintergrund der Verhältnisbestimmung von Konzil und Codex widmet sich die Arbeit der Rechtsstellung der christifideles laici und zeigt, wie auf dem Weg von der Katholischen Aktion zum gemeinsamen Priestertum der Gläubigen der Begriff des Laien in der Kirche neu formuliert und normiert wird. 
Thomas Meckel, Prof. Dr. theol. habil. Lic. iur. can. M.A., Inhaber des Lehrstuhls für Kirchenrecht, Religionsrecht und kirchliche Rechtsgeschichte an der Philosophisch-Theologischen Hochschule Sankt Georgen, Frankfurt/Main.

For more information see brill.com

$$
\begin{aligned}
& \text { Order information: Order online at brill.com } \\
& \text { +44 } 330333 \text { o049 | customerservices@brill.com } \\
& \text { Submission information: brill.com/authors }
\end{aligned}
$$

Titles published by Brill | Fink, Brill | mentis or Brill | Schöningh: +49(o)71 5413279216 | brill@brocom.de 